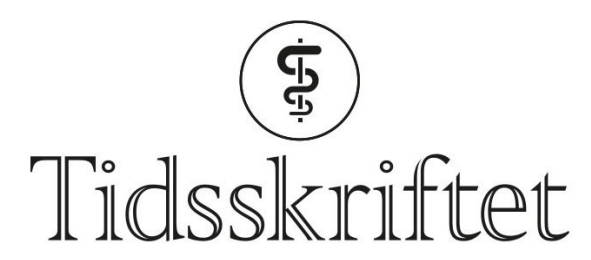

DEN NORSKE LEGEFORENING

\title{
Donders eller Donders' metode?
}

SPRÅKSPALTEN

\section{ERLEND HEM}

E-post: erlend.hem@medisin.uio.no

Erlend Hem (f. 1970) er dr.med., fagsjef og redaktør for Tidsskriftets språkspalte.

Hva er riktig skrivemåte av synsfeltundersøkelsen som er oppkalt etter dr. Donders?

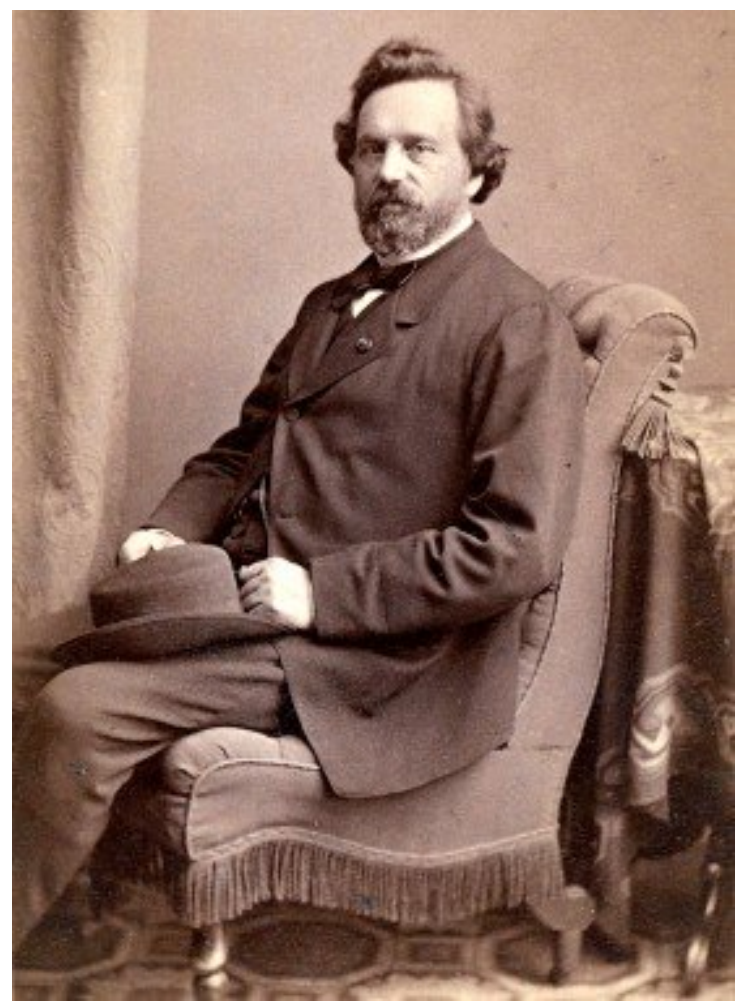

Den nederlandske legen Franciscus Cornelis Donders (1818-89) har gitt navn til Donders' test. Foto: Alexander Seitz

Alle leger lærer å unders $\emptyset$ ke pasienters synsfelt ad modum Donders. Testen har sitt navn etter F.C. Donders (1818-89), lege og professor i Utrecht og en av gigantene i Nederlands medisinhistorie. Men hvordan skal navnet skrives og hva blir riktig genitivsform på norsk?Da Helsedirektoratet skulle oppdatere Førerkortveilederen nylig, undret man på hva som er korrekt skrivemåte (1). Man hadde registrert at i både Store medisinske leksikon og i Tidsskriftet sto det Donders uten apostrof $(2,3)$, mens andre steder, blant annet på en nettside ved Universitetet i Oslo, ble apostrofen brukt (4). Kunne språkspalten oppklare? Det er ingen tvil fra samtidige kilder at navnet ble skrevet med s til slutt: Donders (5-7). Og da gir svaret på spørsmål 2 seg selv: Korrekt genitivsform blir Donders' - med apostrof. 
Hovedregelen i norsk er at genitiv lages ved å føye til en s uten apostrof, s-en henges altså rett på ordet: Pers bil. Men det går ikke når ordene ender på -s, -x og -z. Da setter vi inn en apostrof i stedet: Mons' bil, Vesaas' dikt, Marx' skrifter (8). Medisinske eksempler er Donders' test, His' bunt, Bayes' teorem, Adam-Stokes' syndrom, etc.

Helsedirektoratet har grunn til å spørre, for det står faktisk feil i alle de tre store norske medisinske ordbøkene (9-11). I Gyldendals ordbok er det en logikk, siden navnet angis å være Donder (uten s), men det er altså ikke riktig.

Det er flere eksempler i Lovdata på at apostrofen mangler i Donders' test (12). Men oppryddingen er begynt: Nå står det riktig i førerkortforskriften: Donders’ metode.

\section{LITTERATUR:}

1. Førerkort - veileder til helsekrav. Gjeldende fra 1. oktober 2016. Sist endret 29.4.2017. https://helsedirektoratet.no/Retningslinjer/F\%C3\%B8rerkortveilederen.pdf(2.5.2017).

2. Sandvig K. (13.2.2009). Perimetri. I: Store medisinske leksikon. https://sml.snl.no/perimetri (2.5.2017).

3. Riise R, Gundersen B, Brodal S et al. Synsproblemer ved hjerneslag. Tidsskr Nor Lægeforen 2005; 125: 176 - 7. [PubMed]

4. Synsfeltundersøkelse (ad modum Donders). Universitetet i Oslo. http://meddev.uio.no/journalwiki/index.php/Synsfeltunders\%C3\%B8kelse_(ad_modum_Donders) (2.5.2017).

5. Donders FC. Remarks on colours and colour-blindness. Br Med J 188o; 2: 767 - 9. [PubMed][CrossRef]

6. Obituary. Franz Cornelius Donders. Br Med J 1889; 1: 746. www.bmj.com/content/1/1474/746 (2.5.2017).

7. Franciscus Cornelis Donders. Find a grave. www.findagrave.com/cgi-bin/fg.cgi?pagegr\&GRid= $58925160(2.5 \cdot 2017)$.

8. Hem E. Homans' tegn og Simmonds' syndrom. Tidsskr Nor Legeforen 2011; 131: 487. [PubMed][CrossRef]

9. Donders prøve. I: Øyri A. Norsk medisinsk ordbok. 9. utg. Oslo: Samlaget, 2011: 254.

10. Donders undersøkelse. I: Nylenna M, red. Medisinsk ordbok. 7. utg. Oslo: Kunnskapsforlaget, 2oog: 105 .

11. Donders synfeltstest. I: Lindskog BI. Gyldendals store medisinske ordbok. 2. utg. Oslo: Gyldendal, 2003: 125 .

12. Forskrift om helseundersøkelse av arbeidstakere på norske skip og flyttbare innretninger. Næringsog fiskeridepartementet. https://lovdata.no/dokument/SF/forskrift/2014-06-05-805?qdonders (1.5.2017).

Publisert: 13. november 2017. Tidsskr Nor Legeforen. DOI: 10.4045/tidsskr.17.0632

(C) Tidsskrift for Den norske legeforening 2020. Lastet ned fra tidsskriftet.no 